\title{
SPAD INDEX AND LEAF PIGMENTS IN CAULIFLOWER IN DIFFERENT WATER CONDITIONS AND SILICON FERTILIZATION
}

Gustavo Soares Wenneck*1 (D), Reni Saath ${ }^{1}$ (D), Roberto Rezende ${ }^{1}$ (D) \& Lucas Henrique Maldonado da Silva ${ }^{1}$ (D)

1 - State University of Maringá, Department of Agronomy, Maringá, Paraná, Brazil

\section{Keywords:}

Carotenoids

Chlorophyll
Brassica oleracea var. botrytis

Water management

\section{ABSTRACT}

The measurement of leaf pigments using non-destructive methods can be influenced by water management conditions and the use of nutrients in cauliflower, not showing adequate correlations with chlorophyll contents. The objective of this study was to evaluate the correlation between the SPAD index and the pigment content in cauliflower leaves managed with different water conditions and the application of silicon ( $\mathrm{Si}$ ). The cultivation was carried out in a protected environment in the city of Maringá, Paraná State from October 2019 to March 2020. It was adopted a randomized block design, with treatments in a $3 \times 4$ factorial scheme, with three levels of water recharge (40; 70 and $100 \%$ of crop evapotranspiration (ETc)) and four doses of $\mathrm{Si}(0$; $50 ; 100$ and $\left.150 \mathrm{~kg} \mathrm{ha}^{-1}\right)$, with four replications. Once plants showed developed inflorescence, the SPAD index was determined in the field and the levels of chlorophyll a, chlorophyll $b$, and carotenoids in the laboratory using leaves from the upper third. The correlation between water recharge and Si fertilization on the SPAD index was determined. The proportion of carotenoids in relation to total pigments was compared under different conditions. Correlation analysis was performed considering silicon fertilization, water recharge, leaf pigments, and the SPAD index. Silicon fertilization reduced the levels of carotenoids in addition to being related to chlorophyll a $(100 \%$ of ETc) and chlorophyll $b$ ( $70 \%$ of ETc). The correlation of the SPAD index with pigments is variable with the water condition of the crop, in a condition without water deficit, it is related to chlorophyll a and in a condition of $70 \%$ replacement of ETc, it is correlated with chlorophyll b.

\section{Palavras-chave: Brassica oleracea var. botrytis Carotenoides}

ÍNDICE SPAD E PIGMENTOS FOLIARES EM COUVE-FLOR EM DIFERENTES

Clorofila

Manejo hídrico

\section{CONDIÇÕES HÍDRICAS E ADUBAÇÃO SILICATADA}

\section{RESUMO}

A mensuração dos pigmentos foliares, por métodos não destrutivos, pode ser influenciada pelas condições de manejo hídrico e pela utilização de nutrientes na couve-flor, não apresentando correlações adequadas com teores de clorofila. O estudo objetivou avaliar a correlação entre o índice SPAD e o conteúdo de pigmentos em folhas de couve-flor manejadas com diferentes condições hídricas e aplicações de silício ( $\mathrm{Si}$ ). O cultivo foi conduzido em ambiente protegido no município de Maringá-PR entre outubro de 2019 e março de 2020. Foi adotado delineamento de blocos casualizados, com tratamentos em esquema fatorial $3 \times 4$, sendo três níveis de reposição hídrica (40; 70 e 100\% da evapotranspiração da cultura (ETc)) e quatro doses de $\mathrm{Si}(0 ; 50 ; 100$ e $150 \mathrm{~kg} \mathrm{ha}^{-1}$ ), com quatro repetições. Com plantas apresentando inflorescência desenvolvida, foi realizada a determinação do índice SPAD à campo e os teores de clorofila a, clorofila b e carotenoides em laboratório utilizando folhas do terço superior. Foi determinada a correlação da reposição hídrica e a adubação com Si sobre o índice SPAD. A proporção de carotenoides em relação aos pigmentos totais foi comparada nas diferentes condições. Foram realizadas análise de correlação considerando a adubação silicatada, a reposição hídrica, os pigmentos foliares e o índice SPAD. A adubação silicatada reduziu os teores de carotenoides, e apresentou relação com clorofila a (100\% da ETc) e clorofila b $(70 \%$ da ETc). A correlação do índice SPAD com pigmentos é variável com a condição hídrica da cultura, sendo em condição sem déficit hídrico relacionado com a clorofila a e em condição de reposição de $70 \%$ da ETc correlacionado com clorofila b. 


\section{INTRODUCTION}

The cultivation of cauliflower (Brassica oleracea var. botrytis) stands out among horticultural species, with a volume sold of greater than 80 thousand $t$ year-1between 2016 and 2018, considering only the supply centers (RIBEIRO et al., 2019). Regarding growth conditions, it requires mild temperature and adequate water availability during its cycle (MAY et al. 2007).

In water deficit conditions, cauliflower may show a reduction in photosynthetic activity, morphological development, and yield (VIDIGAL et al., 2018, HACHMANN et al., 2019). Under such conditions, crops tend to change morphological characteristics by changing leaf insertion angle, reducing transpiration through the regulation of the stomatal opening, and modifying leaf pigment contents to adapt to conditions to allow maximum efficiency in the use of resources (FRANÇA et al., 2017; MARQUES et al., 2011; TAIZ et al., 2017). Such responses to stress conditions (biotic or abiotic) can be mitigated by using beneficial elements such as silicon (BARRETO et al., 2017; CURVELO et al. 2017; RODRIGUES et al., 2016).

The content of leaf pigments is directly linked to the photosynthetic capacity of the plant, so the change in the content of these pigments may indicate that the plant is under stress conditions (SANTOS et al., 2011). The contents of leaf pigment are determined by extracting these pigments, using the destructive method. This method allows quantifying the levels of chlorophyll a, chlorophyll b, and carotenoids (LICHTENTHALER, 1987). Nondestructive methods can be used to estimate the characteristics of pigments in leaves, also allowing for adequate crop management. The SPAD (Soil Plant Analysis Development) is one of the main non-destructive methods that is used as a support tool for the definition of management strategies, quantifying pigments at wavelengths of 650 and $940 \mathrm{~nm}$ (COELHO et al., 2018; NOGUERIA et al., 2018; PÔRTO et al., 2011; VIDIGAL et al., 2018).

Although the SPAD index indirectly quantifies the content of leaf pigments and is used to assess the nutritional status of plants, changes in crop management may be not be detected through the method (NOGUERIA et al., 2018; NASSER et al., 2020). The correlation with chlorophyll contents can also be influenced by the species under analysis and by the environmental and management conditions (COELHO et al., 2018; MAIA JUNIOR et al., 2017; VIDIGAL et al., 2021).

Studies involving the determination of the SPAD index in horticultural species, specifically in the cauliflower crop, are still limited, which impairs the determination of suitable ranges under growing conditions. Therefore, the objective of this study was to evaluate the correlation between the SPAD index and the pigment content in cauliflower leaves managed with different water conditions and silicon dose applications.

\section{MATERIAL AND METHODS}

The experiment was conducted in a greenhouse at the State University of Maringá $\left(23^{\circ} 25^{\prime} \mathrm{S}\right.$, $51^{\circ} 57^{\prime} \mathrm{W}$ and $542 \mathrm{~m}$ above sea level), in the municipality of Maringá, Paraná State. Field conduction occurred from October 2019 and February 2020, with relative humidity ranging from 58 to $98 \%$ and temperature from 16 to $37^{\circ} \mathrm{C}$ inside the protected environment.

The experiment used the randomized block design, in a $3 \times 4$ factorial, with three water replacement conditions $(40 ; 70$ and $100 \%$ of crop evapotranspiration (ETc)) and four silicon doses $\left(0 ; 50 ; 100\right.$ and $\left.150 \mathrm{~kg} \mathrm{ha}^{-1}\right)$ with four repetitions.

Cultivar Sharon was evaluated in this work, as it is adapted to mid-season periods (MAY et al. 2007). The crop was implanted using seedlings 30 days after sowing and conducted in beds $(0.5 \times 3$ $\mathrm{m})$. Water was recharged employing drip irrigation $\left(5 \mathrm{~L} \mathrm{~h}^{-1}\right)$ considering the ETc, determined with constant water table lysimeters inside the protected environment.

The soil is classified as Dystroferric Red Nitosol (SANTOS et al., 2018), with a very clayey texture. Tillage was done using a motor cultivator and fertilized using $30 \mathrm{~kg} \mathrm{ha}^{-1}$ of $\mathrm{N}$ (urea), $250 \mathrm{~kg}$ ha $^{-1}$ of $\mathrm{P}_{2} \mathrm{O}_{5}$ (simple superphosphate), $100 \mathrm{~kg} \mathrm{ha}^{-1}$ of $\mathrm{K}_{2} \mathrm{O}$ (potassium chloride), and $4 \mathrm{~kg} \mathrm{ha}^{-1}$ of $\mathrm{B}$ (boric acid), according to soil nutrient content and crop recommendations (PAULETTI and MOTTA, 2017). Silicon (Si) was applied using the product AgriSil $^{\circledR}\left(98 \% \mathrm{SiO}_{2}\right)$ in the form of wettable powder. The doses of $\mathrm{Si}(50,100$, and $\left.150 \mathrm{~kg} \mathrm{ha}^{-1}\right)$ were split ( $1 / 3$ of the dose) into phases I (from transplanting until the plant had 7 to 10 leaves), II (7 to 10 leaves until the occurrence of inflorescence in the meristem) and III (from the presence of inflorescence to harvest), according to 
the classification proposed by Allen et al. (1998). The doses were applied via fertigation.

In phase III (ALLEN et al., 1998) with the inflorescence developed, the SPAD index was determined in the upper-third leaves, using the SPAD-502 Plus ${ }^{\circledR}$ (Minota) equipment with readings taken between 8 and 9 a.m. In the leaves where the SPAD index was determined, segments were collected to determine the pigment content (chlorophyll and carotenoids). For extraction of leaf pigments (chlorophyll a, chlorophyll $\mathrm{b}$, and carotenoids), $150 \mathrm{mg}$ of fresh mass were kept in the absence of light and at low temperature, in pure acetone to remove the pigments. The determination of leaf pigments was performed using a double beam UV-VIS spectrophotometer (model AJX-6100PC), using quartz cuvettes (3.5 $\mathrm{mL}$ ), with readings at $661.4 ; 644.8$ and $470 \mathrm{~nm}$, employing pure acetone as blank, according to the methodology described by Lichtenthaler (1987).

Data on the SPAD index under the conditions of fluid replacement and Si doses are presented by Wenneck et al. (2021), and the water replacement conditions were compared by means of the test of the means and the application of Si with polynomial regression using univariate mathematical equations.

For data analysis of this study, the SPAD index was analyzed using a multivariate polynomial regression approach, with an equation considering the two analyzed factors (water replacement and Si dose) and correlated with the contents of chlorophyll a, chlorophyll $\mathrm{b}$, total chlorophyll (a $+b$ ), carotenoids (carotene + xanthophylls) and sum of pigments (chlorophyll + carotenoids). Regarding multivariate polynomial regression analysis and determination of the $\mathrm{R}^{2}$ coefficient of the model, the Surfer 10 software was used. Determination of the Pearson linear correlation was done using Excel ${ }^{\circledR}$ software.

\section{RESULTS AND DISCUSSION}

Considering a significant effect $(\mathrm{p}<0.05)$ on the interaction between the level of water recharge and silicon application, the mathematical equation (Equation 1) was estimated, which presents the multiple coefficients of determination $\left(\mathrm{R}^{2}\right)$ equal to 0.84 , allowing the estimation of the impact of conditions on the SPAD index in leaves of the upper third of cauliflower grown in a greenhouse. Graphical analysis can be performed as shown in Figure 1.
$S P A D=-1.46575+(0.466792 * \mathrm{ETc})+(0.110627 * \mathrm{Si})$

In which,

SPAD $=$ SPAD index (dimensionless);

ETc $(\%)=$ water regharge according to the crop evapotranspirtation;

$\mathrm{Si}=$ Applied silicon dose $\left(\mathrm{kg} \mathrm{ha}^{-1}\right)$.

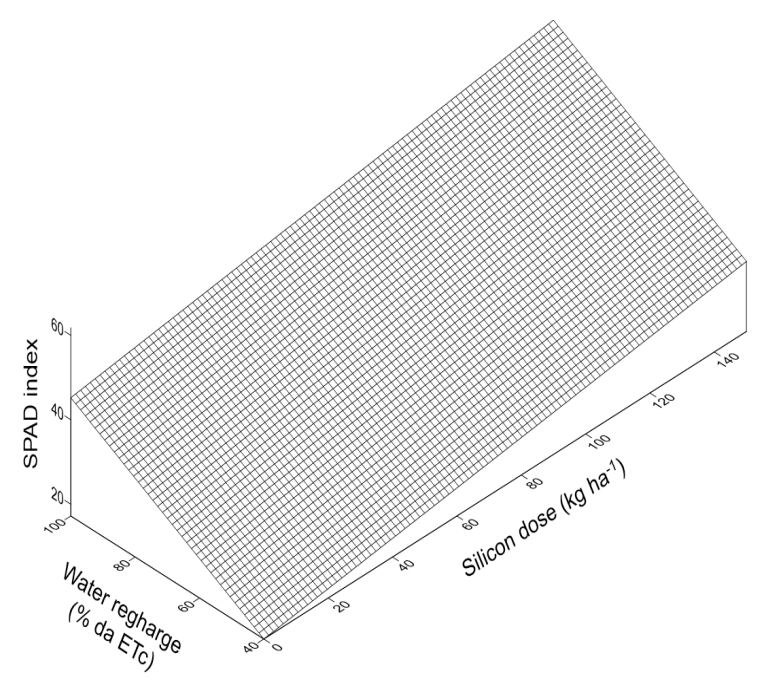

Figure 1. Multivariate regression for the SPAD index in cauliflower leaves at flowering, as a function of water recharge and silicon fertilization

The imposition of water deficit, according to Wenneck et al. (2021), has a significant effect on the SPAD index, and Si application may attenuate the stress effects. Works involving Si application found positive effects related to the element on nutrient absorption, photosynthetic efficiency, protection against pathogen and insect attacks, toxicity attenuation, and commercial quality of cauliflower inflorescence in the post-harvest stage (MENEGALE et al., 2015; SOUZA et al., 2015, BARRETO et al., 2017; CURVELO et al., 2017).

Regarding plant development, the imposition of water restriction may have direct effects on the mass accumulation by the plant and on the SPAD index measured in the leaves throughout cultivation, as observed by Coelho et al. (2018) in oat crops. However, considering the species and the analyzed factor, differences in the SPAD index may not present significant changes, being mainly associated with the nitrogen content in the leaf (ARAGÃO et al., 2020; NASSER et al., 2020; VIDIGAL et al., 2021).

For the experimental conditions, the mathematical model allowed us to predict that the increment in the amount of $\mathrm{Si}$ raises the values of 
the SPAD index in the different water conditions of the crop. Considering that the technique of determining the SPAD index is mostly used to indirectly measure the content and response of the plant to $\mathrm{N}$, the results obtained also reflect the nutritional status of the plant (NOGUERIA et al., 2018; VIDIGAL et al., 2018).

The determination of the SPAD index can also be correlated with the total chlorophyll content in studies with water regimes (MAIA JUNIOR et al., 2017). Thus, based on the quantification of the evaluated leaf pigment contents and the correlation analysis with global data, it was observed that the carotenoids had a higher correlation with the SPAD index (-0.56), in which the negative value represents an inverse behavior between the variables. For chlorophyll a, chlorophyll $b$, and for the sum of leaf pigments, a low correlation was observed with the SPAD index (Table 1).

Considering the expression of the correlation results (Table 1), it was observed that the total chlorophyll $(a+b)$ was largely related to the sum of pigments (0.99), while a negative correlation was obtained between carotenoids and chlorophylls. The correlation between the SPAD index with the leaf pigments allows indirect prediction of leaf components, as obtained in sunflower, where the total chlorophyll can be calculated considering the SPAD index (MAIA JÚNIOR et al., 2017). In horticultural species such as tomatoes, the correlation between indirect measures, determined by non-destructive methods such as SPAD, and levels directly determined by destructive methods such as quantification by extraction, was significant and positive (NOGUEIRA et al., 2018).

The percentage of carotenoids was higher at recharge levels of 40 and $70 \%$ of ETc without $\mathrm{Si}$ application (Figure 2), due to pigment synthesis in response to water deficit (SILVA et al., 2016; TAIZ et al., 2017). The application of $50 \mathrm{~kg} \mathrm{ha}^{-1}$ of $\mathrm{Si}$ resulted in a significant decrease in the replacement of $40 \%$ of ETc, from 33.8 to $15.6 \%$, while for $70 \%$ of ETc, a decrease from 22.3 to $15.6 \%$ was observed.

Table 1. Correlation between leaf pigments and SPAD index

\begin{tabular}{ccccccc}
\hline & Chlorophyll a & Chlorophyll b & $\begin{array}{c}\text { Total } \\
\text { chlorophyll }\end{array}$ & Carotenoid & $\begin{array}{c}\text { Sum of the } \\
\text { pigments }\end{array}$ & SPAD \\
\hline Chlorophyll a & 1.00 & - & - & - & - & - \\
Chlorophyll b & 0.45 & 1.00 & - & - & - & - \\
Total chlorophyll & 0.85 & 0.85 & 1.00 & - & - & - \\
Carotenoids & -0.19 & -0.62 & -0.48 & 1.00 & - & - \\
Sum of the pigments & 0.87 & 0.81 & 0.99 & -0.34 & 1.00 & - \\
SPAD & 0.16 & 0.12 & 0.18 & -0.56 & 0.10 & 1.00 \\
\hline
\end{tabular}

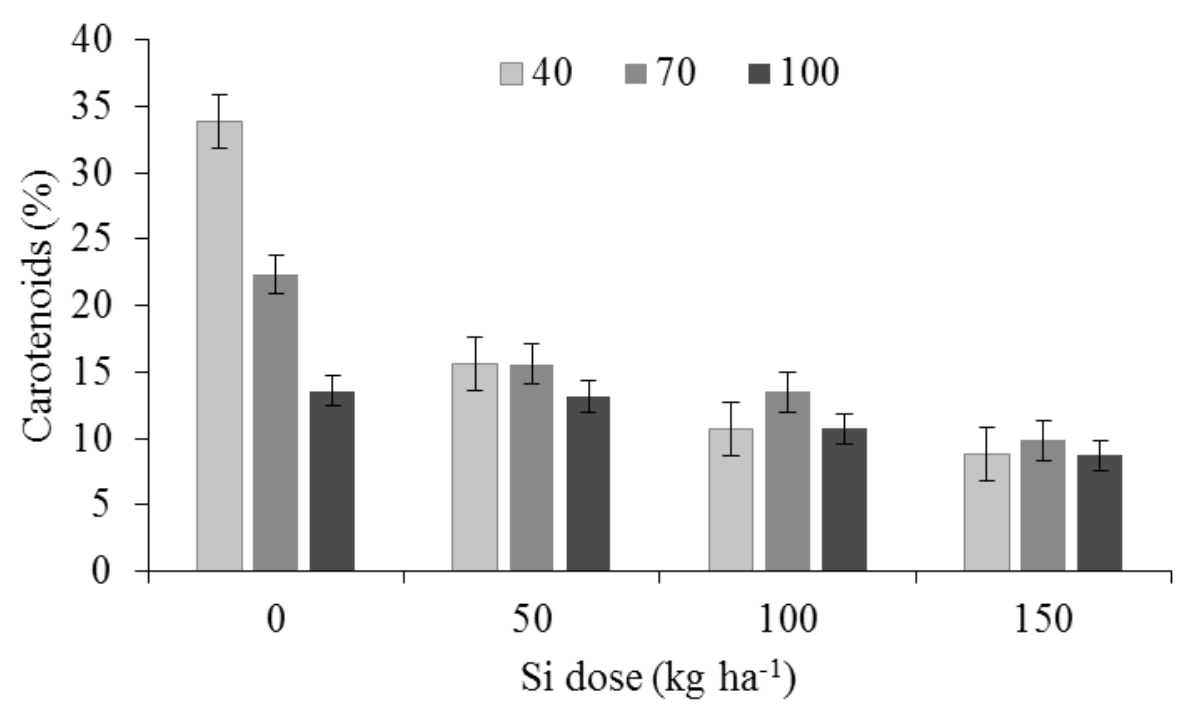

Figure 2. Carotenoid proportion (\%) in total pigments in cauliflower leaves at flowering as a function of silicon application $\left(\mathrm{kg} \mathrm{ha}^{-1}\right)$ 
The tendency to reduce the content of carotenoids was maintained for all recharge levels according to the addition of silicon fertilization, indicating a mitigating effect of $\mathrm{Si}$ on water deficit (Figure 2).

In the condition without water deficit $(100 \%$ of ETc) there was a high positive correlation with chlorophyll a, and negative with carotenoids. In the condition of moderate water deficit $(70 \%$ of ETc), a high correlation with chlorophyll $b$ was observed. In the condition of severe water deficit ( $40 \%$ of ETc), it was reported a high correlation with carotenoids, being negative (-0.99), as shown in Table 2.

In a study carried out using rice, it was determined that the application of $\mathrm{Si}$ raised the levels of chlorophyll a and chlorophyll $b$, with an impact on the productive components (ÁVILA et al., 2010). In tomatoes, silicon fertilization $\left(\mathrm{K}_{2} \mathrm{SiO}_{3}\right)$ incremented the levels of chlorophyll a (RODRIGUES et al., 2016). Silicate fertilization correlated at different levels according to the water conditions (Table 2).

Considering the dynamics in leaf pigment contents associated with the environmental and management conditions of the crop of interest (MARQUES et al., 2011; FRANÇA et al., 2017; MOURA NETO et al., 2021), and the differences in the proportion of carotenoids (Figure 2), it was proposed to analyze the correlation of the SPAD index with the pigments, in each condition of water recharge (Table 3).
In water deficit conditions, increments were observed in the levels of chlorophyll $b$ in order to improve photosynthetic efficiency (FRANÇA et al., 2017). In the condition of mild water deficit ( $70 \%$ of ETc), the SPAD index was particularly correlated to chlorophyll b contents (Table 3 ).

The contents of chlorophyll $b$ and total chlorophyll are mostly influenced by environmental conditions, while chlorophyll a is associated with crop management (MOURA NETO et al., 2021). In the condition of cultivation without water deficit, the correlation was higher with total chlorophyll (Table 3), showing that the determination of the SPAD index indirectly allows the estimation of chlorophyll levels in cauliflower.

In conditions of severe water deficit $(40 \%$ of ETc) no correlations greater than 0.3 were observed. Possibly, the high-stress condition caused photooxidation damage, impairing pigment dynamics, photosynthetic efficiency, and plant growth (MARQUES et al., 2011; TAIZ et al., 2017). In this context, the determination of the SPAD index does not present practical efficiency, considering the water management as a limiting factor for plant growth.

Further studies addressing this topic should be considered, especially with the use of other cultivars, planting times, and production locations. Thus, being able to consolidate more extensively the SPAD index as a tool to estimate levels of leaf pigments in cauliflower.

Table 2. Correlation between silicon fertilization and leaf pigment contents and SPAD index

\begin{tabular}{ccccccc}
\hline $\begin{array}{c}\text { Water } \\
\text { recharge } \\
(\% \text { \%Tc) }\end{array}$ & Chlorophyll a & Chlorophyll b & $\begin{array}{c}\text { Chlorophyll } \\
\mathbf{a}+\mathbf{b}\end{array}$ & Carotenoids & $\begin{array}{c}\text { Sum of the } \\
\text { pigments }\end{array}$ & SPAD \\
\hline 100 & 0.99 & 0.85 & 0.96 & -0.99 & 0.95 & -0.05 \\
70 & -0.46 & 0.99 & 0.59 & -0.88 & 0.08 & 0.94 \\
40 & 0.80 & 0.58 & 0.93 & -0.99 & 0.91 & 0.97 \\
\hline
\end{tabular}

Table 3. Correlation between SPAD index and leaf pigments at different water-deficit levels in cauliflower.

\begin{tabular}{cccccc}
\hline $\begin{array}{c}\text { Water recharge } \\
\text { (\% ETc) }\end{array}$ & Chlorophyll a & Chlorophyll b & $\begin{array}{c}\text { Chlorophyll } \\
\mathbf{a + b}\end{array}$ & Carotenoid & $\begin{array}{c}\text { Sum of the } \\
\text { pigments }\end{array}$ \\
\hline 100 & 0.69 & 0.57 & 0.84 & -0.95 & 0.84 \\
70 & -0.74 & 0.89 & 0.29 & -0.98 & -0.27 \\
40 & -0.10 & 0.29 & 0.10 & 0.19 & 0.12 \\
\hline
\end{tabular}




\section{CONCLUSIONS}

- The SPAD index determined in cauliflower leaves can be represented by a multivariate mathematical equation, considering the silicon doses and water replacement levels.

- Silicon fertilization reduced the proportion of carotenoids in leaves.

- Silicon fertilization in the condition without water deficit $(100 \%$ of ETc) showed a correlation with chlorophyll a; with a recharge of $70 \%$ of ETc, correlation with chlorophyll b, and with recharge of $40 \%$ of ETc, a negative correlation with carotenoids.

- The determination of the SPAD index is negatively correlated with the content of carotenoids in conditions of water recharge of 70 and $100 \%$ of ETc.

\section{AUTHORSHIP CONTRIBUTION STATEMENT}

WENNECK, G.S.: Conceptualization, Data curation, Investigation, Writing - original draft, Writing - review \& editing; SAATH, R.: Conceptualization, Resources, Supervision; REZENDE, R.: Conceptualization, Resources, Supervision; SILVA, L.H.M.: Data curation, Writing - original draft, Writing - review \& editing.

\section{DECLARATION OF INTERESTS}

The authors declare that they have no known competing financial interests or personal relationships that could have appeared to influence the work reported in this paper.

\section{ACKNOWLEDGEMENTS}

This work was carried out with the support of the Coordenação de Aperfeiçoamento de Pessoal de Nível Superior - Brazil (CAPES) Financing Code 001 and the Conselho Nacional de Desenvolvimento Científico e Tecnológico (CNPq).

\section{REFERENCES}

ALLEN, R. G.; PEREIRA, L. S.; RAES, D.; SMITH, M. Crop evapotranspiration guidelines for computing crop water requirements. Rome: FAO, 1998.

ARAGÃO, M. M.; OLIVEIRA, G. R. C.; NEVES, J. L.; ANJOS, D. N. Resposta da cultura da alface em função de diferentes saturações por bases. PesquisAgro, Confresa, v.3, n.1, p.94-101, 2020.

ÁVILLA, F. W.; BALIZA, D. P.; FAQUIN, V.; ARAÚJO, J. L.; RAMOS, S. J. Interação entre silício e nitrogênio em arroz cultivado sob solução nutritiva. Revista Ciência Agronômica, Fortaleza, v. 41, n. 2, p. 184-190, 2010.

BARRETO, R. F.; SCHIAVON JÚNIOR, A. A.; MAGGIO, M. A.; PRADO, R. D. Silicon alleviates ammonium toxicity in cauliflower and in broccoli. Scientia Horticulturae, v.225, p.743-750, 2017.

FRANÇA, P. H. T.; SILVA, E. C. A.; SILVA, T. C.; BRASIL, N. A.; NOGUEIRA, R. J. M. C. Análise fisiológica em mudas de guanandi (Calophyllum brasiliense Cambess) submetidas ao déficit hídrico. Agropecuária Científica no Semiárido, Patos, v.13, n.4, p.264-269, 2017.

HACHMANN, T. L.; REZENDE, R.; PINTRO, P. T. M.; SAATH, R.; ANJO, F. A.; MENEZES, C. S. L. Yield, antioxidant activity and shelflife of cauliflower inflorescences under drought stress and foliar spraying of selenium. Ciência e Agrotecnologia, Lavras, v. 43, e017819, 2019.

MAIA JÚNIOR, S. O.; ANDRADE, J. R.; FERREIRA, R. S.; ARAÚJO, D. L.; GUERRA, H. O. C.; SILVA, F. G. Teores de pigmentos, fluorescência da clorofila a e índice SPAD em cultivares de girassol sob regimes hídricos. Revista Agrarian, Dourados, v.10, n.36, p.105-112, 2017.

MARQUES, R.P.; FREIRE, C. S.; NASCIMENTO, H. H. C.; NOGUEIRA, R. J. M. C. Relações hídricas e produção de pigmentos fotossintéticos em mudas de Eugenia uniflora L. sob condições de salinidade. Revista Brasileira de Geografia Física, v. 4, n. 3, p. 497-509, 2011. 
MOURA NETO, A.; MOURA, B. S.; SILVA, L. L. S.; PORTELA, W. N.; LIMA, E. A.; GONÇALVES JUNIOR, A. S.; RODRIGUES, L. S.; ROCHA, J. G. J. H. Teores de clorofila da rúcula em função de diferentes ambientes e doses de esterco caprino. Brazilian Journal of Development, Curitiba, v.7, n.1, p.6502-6512, 2021.

NASSER, M. D.; CARDOSO, A. I. I.; VIEITES, R. L.; NASSER, F. A. C. M.; FURLANETO, K. A.; RAMOS, J. A.; CAETANO, P. K.; SANTOS, J. A. Effects of organic compost, gypsum, and topdress sulfur rates on bioactive compounds and physicochemical characteristics of collard greens. Scientia Plena, v.16, n.9, e090201, 2020.

NOGUEIRA, B. B.; IGLESIAS, L.; MESQUITA, J. V.; NAKATANI, M. C.; PUTTI, F. F. Índice SPAD em plantas de tomateiro cultivado em fibra de coco e submetido a pulsos de fertirrigação. Brazilian Journal of Biosystems Engineering, v. 12, n.1, p.1-6, 2018.

MAIA JÚNIOR, S. O.; ANDRADE, J. R.; FERREIRA, R. S.; ARAÚJO, D. L.; GUERRA, H. O. C.; SILVA, F. G. Teores de pigmentos, fluorescência da clorofila a e índice SPAD em cultivares de girassol sob regimes hídricos. Revista Agrarian, Dourados, v.10, n.36, p.105-112, 2017.

PÔRTO, M. L; PUIATTI, M.; FONTES, P. C. R.; CECON, P. R.; ALVES, J. C.; ARRUDA, J. A. Índice SPAD para o diagnóstico do estado de nitrogênio na cultura da abobrinha. Horticultura Brasileira, Brasília, v.29, n.3, p. 311-315, 2011.

RIBEIRO, C.; MORAIS, L. C. C.; MENDES, A. R.; MARCOMINI, L. R. S.; GONÇALVES, I. C. Pequenos mercados, grandes valores! In: Hortifruti Brasil. Centro de Estudos Avançados em Economia (CEPEA) Ano 17, n.188, 2019.

RODRIGUES, C. R.; RODRIGUES, T. M.; LUZ, J. M. Q.; SOUSA, V. B. F.; SOUSA, J. B.; NUNES, A. C. P.; TRINDADE, P. R. Clorofila a e b de tomateiro tratado com silicato de potássio e fungicida. Global Science and technology, v.9, n.2, p.54-64, 2016.
LICHTENTHALER, H. K. Chlorophylls and carotenoids: pigments of photosynthetic biomembranes. Methods in Enzymology, v.148, p.350-382, 1987.

SANTOS, E. R.; BORGES, P. R. S.; SIEBENEICHLER, S. C.; CERQUEIRA, A. P.; PEREIRA, P. R. Crescimento e teores de pigmentos foliares em feijão-caupi cultivado sob dois ambientes de luminosidade. Revista Caatinga, Mossoró, v.24, n.4, p.14-19, 2011.

SANTOS, H. G.; JACOMINE, P. K. T.; ANJOS, L. H. C.; OLIVEIRA, V. Á.; LUMBRERAS, J. F.; COELHO, M. R.; ALMEIDA, J. A.; ARAÚJO FILHO, J. C.; OLIVEIRA, J. B.; CUNHA, T. J. F. Sistema Brasileiro de Classificação de Solos. 5. ed. Brasília: EMBRAPA, 2018.

SILVA, A. R. A.; BEZERRA, F. M. L.; LACERDA, C. F.; SOUSA, C. H. C.; CHAGAS, K. L. Pigmentos fotossintéticos e potencial hídrico foliar em plantas jovens de coqueiro sob estresses hídrico e salino. RevistaAgro@mbiente On-line, Boa Vista, v. 10, n. 4, p. 317-325, 2016.

TAIZ, L.; ZEIGER, E.; MÖLLER, I. M.; MURPHY, A. Estresse abiótico. In: Fisiologia e desenvolvimento Vegetal. $6^{\text {a }}$ ed., Porto Alegre: Artmed, 2017.

VIDIGAL, S. M.; LOPES, I. P. C.; PUIATTI, M.; RIBEIRO, M. R. F.; SEDIYAMA, M. A. N. SPAD index in the diagnosis of nitrogen status in cauliflower as a function of nitrogen fertilization. Científica, Jaboticabal, v.46, n.3, p.307-314, 2018.

VIDIGAL, S. M.; PUIATTI, M.; LOPES, I. P. C.; SEDIYAMA, M. A. N. Nitrogen content, SPAD index and production of single head broccoli. Horticultura Brasileira, Brasília, v.39, n.1, p.5257, 2021.

WENNECK, G. S.; SAATH, R.; REZENDE, R.; ANDREAN, A. F. B. A.; SANTI, D. C. . Resposta agronômica de couve-flor à adição de silício ao solo sob estresse hídrico. Pesquisa Agropecuária Tropical, Goiânia, v. 51, e66908, 2021. 